\title{
Climate Change Adaptation: Implications for Food Security and Nutrition
}

\author{
Caroline Fadeke Ajilogba and Sue Walker
}

\section{Contents}

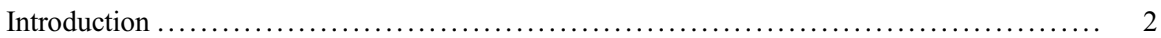

Climate Change and Reality ................................................. 3

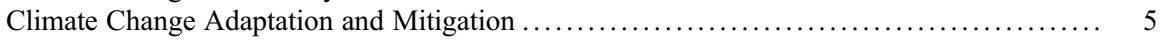

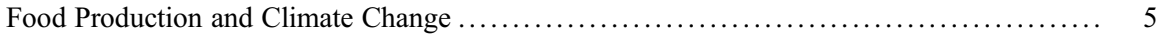

Climate Change Impact on Food Availability .................................. 8

Climate Change Impact on Food Accessibility ............................... 9

Climate Change Impact on Food Utilization $\ldots \ldots \ldots \ldots \ldots \ldots \ldots \ldots \ldots \ldots \ldots \ldots \ldots \ldots, \quad 9$

Climate Change Impact on Food System ................................... 10

Impact of Climate Change Adaptation on Food Security and Nutrition ................ 10

Crop Diseases and Effects on Crop Yields .................................... 11

Climate Change Impact on the Spread of Plant and Animal Pests and Diseases ......... 12

Climatic Conditions Favoring Crop Diseases: Wheat Rust Disease Example ........... 12

Climatic Change Impact Postharvest .................................... 13

Climate Change Impact on Microbial Biodiversity ............................. 14

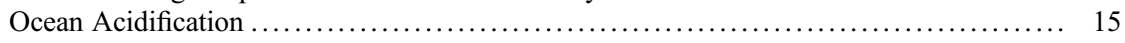

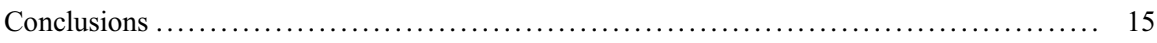

This chapter was previously published non-open access with exclusive rights reserved by the Publisher. It has been changed retrospectively to open access under a CC BY 4.0 license and the copyright holder is "The Author(s)". For further details, please see the license information at the end of the chapter.

\section{F. Ajilogba}

Division of Agrometeorology, Agricultural Research Council - Soil, Climate and Water, Pretoria, South Africa

e-mail: ajilogbac@arc.agric.za

S. Walker $(\bowtie)$

Division of Agrometeorology, Agricultural Research Council - Soil, Climate and Water,

Pretoria, South Africa

Department of Soil, Crop and Climate Sciences, University of the Free State, Bloemfontein, South Africa

e-mail: walkers@arc.agric.za 


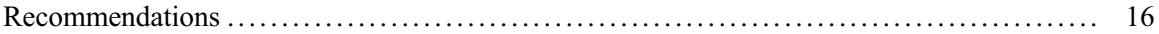

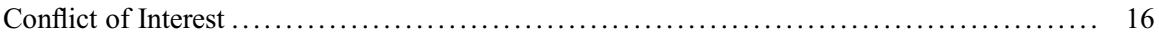

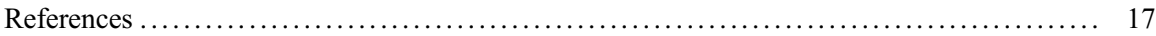

\section{Abstract}

It is apparent that climate change affects every facet of life as no living organism lives outside of the universal environment (air, water, land), and all of these are affected by one or more climate or weather conditions. Climate affects agriculture and vice versa as they are deeply interconnected. The effect of climate change on agriculture goes a long way to increase or decrease food security and invariably food nutrition through its impacts on agricultural lands. This is because the more food insecurity there is, the more issues of undernutrition are observed.

This chapter studies the different ways climate and climate change affect crop production through the different sections of agriculture in terms of plant diseases and biocontrol, food production, livestock rearing, fish production, forestry, and microbial diversity. It goes further to look at the different ways nations and communities are adapting to climate change to mitigate the challenges of food insecurity and nutrition. Finally, some of the solutions that can be pilot tested at the community level, which can later be cascaded to national and regional levels, are also emphasized. Other recommendations that can become a research focus to forestall this threat are also highlighted and would be important in policy development.

\section{Keywords}

Climate change $\cdot$ Environment $\cdot$ Food availability $\cdot$ Food production $\cdot$ Food security $\cdot$ Nutrition $\cdot$ Soil $\cdot$ Weather

\section{Introduction}

Food security has been affected by a change in climate and weather conditions globally. Recently it is also obvious that food nutrition security needs to be addressed. Agriculture is important for food security in two ways: it produces the food people eat and (perhaps even more important) it provides the primary source of livelihood for $36 \%$ of the world's total workforce (ILO 2007). The Food and Agriculture Organization (FAO) of the United Nations (UN) defined food security at the World Food Summit in 1996 as "when all people, at all times have physical and economic access to sufficient, safe and nutritious food to meet their dietary needs and food preferences for an active and healthy life" (Food and Agriculture Organization 1996). Food security transcends food availability (production, distribution, and exchange) but also include how food is accessed (affordability, allocation and preference), utilized (food safety, nutrition, and social value) and also how it is distributed in the supply chain (food stability) (Ziervogel and Frayne 2011). This also means that it is not just about food but how available food is. And even when it is available, communities and individuals might be food insecure if they are not able to access food either because of monetary incapacitation or because of lack of 
knowledge of where to acquire the food, based on their livelihoods and socioeconomic level. It could also be as a result of how safe the food is especially in terms of processes followed during food preparation (Ziervogel and Ericksen 2010).

Agriculture, forestry, and fisheries have all been affected by climate change, and they have contributed to the increase in greenhouse gas emissions, thus affecting climate change negatively. The solution to climate change also partly lies within this sector, if agriculture is able to mitigate climate change through reduction of greenhouse gas emission during sustainable agricultural practices (Al et al. 2008).

Adaptation to climate change can constitute a range of interventions across all levels from individuals to communities to regional and national level. As observed by Bierbaum et al. (2013), communities can initiate their climate adaptation efforts in numerous ways. For example, in the United States, some diverse strategies employed by different communities to combat the issue of climate change include:

- Focusing on internal operations

- Beginning with a sector that is particularly vulnerable to climate change

- Integrating climate change concerns into existing planning approaches

- Conducting a community-wide assessment

The results from these experiments with adaptation strategies demonstrate that there is no "one size fits all" adaptation process or adaptation action (Bierbaum and Stults 2013). This is quite important to note in adaptation plans; however, the information required and the approached to adaptation can be similar across regions and sectors. Therefore, strategies that encourage data and best practices sharing, practical approaches, collaborative, and integrative processes will be important in developing adaptation plans in different countries.

\section{Climate Change and Reality}

Climate change occurs when changes in the Earth's climate system result in new weather patterns that last for at least a few decades and maybe for millions of years. Effects of climate change are seen in the frequency and severity of extreme weather events including droughts, floods, new rainfall patterns, and heatwaves. Increases in temperature have led to an escalation in the distribution of weeds, pests, and diseases some of which are a threat to marine life, plants, animals, and humans. In the same vein, an increase in extreme weather events has led to soil erosion (by water and wind) and loss of arable land for forestry and agriculture.

Impact of climate change on food production cannot be overemphasized; it is enormous and felt more acutely in developing and the least developed nations (Fig. 1). Flooding and droughts have been observed to ruin crops and pastures already being cultivated on the fields. Losses due to floods and droughts between 2004 and 2014 have been estimated to be over 100 billion USD globally (Food and Agriculture Organization 2015; Brida et al. 2013). 


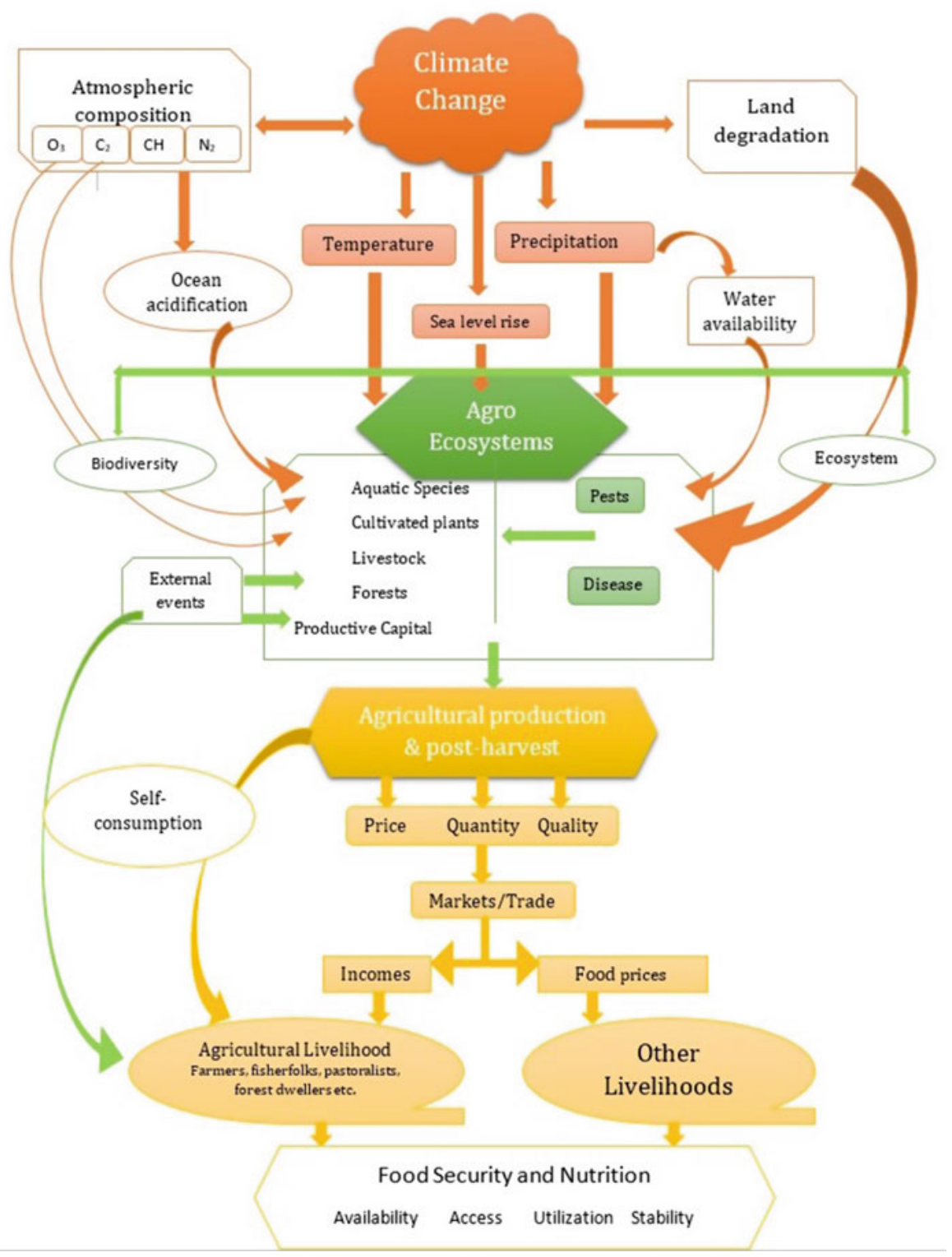

Fig. 1 The interrelatedness between climate change, food security and nutrition showing the impact of climate change on food security. (Adapted from FAO 2016)

Agriculture and fisheries are extremely climate dependent. Temperature and carbon dioxide $\left(\mathrm{CO}_{2}\right)$ increases in some areas can increase some agricultural productivity. Nevertheless, the higher demand for nutrients, soil moisture, water availability, and other requirements must also be met in order to realize these benefits. 
Changes in drought and flood frequency as well as intensity can present severe threats for farmers and ranchers and therefore threaten food safety (Ziska et al. 2016). In addition, warmer water temperatures are likely to trigger a change in the habitat ranges of many species of fish and shellfish, which may threaten ecosystems. Furthermore, climate change could make it harder to produce food and fish and raise livestock in the same way and in the same places as in the past (Chen 2015).

\section{Climate Change Adaptation and Mitigation}

Adaptation to climate change is a way of responding to global climate change (also called "climatic change" or "anthropogenic climate change"). According to The Intergovernmental Panel on Climate Change (IPCC), adaptation is sequence of modifications to actual or expected climate and the impacts of the modification. Adaptation is aimed at mitigating or preventing harm or manipulating beneficial possibilities within human systems. Sometimes, the contributions of human beings enhance adaptations to these modifications and its impacts (IPCC 2014). This requires intentional efforts in the human environmental system to adapt behavioral patterns, lifestyles, and perceptions that can lower the risk to human lives and livelihoods, while mitigation involves coordinated actions to reduce long-term emissions of greenhouse gases ( $\mathrm{Al}$ et al. 2008). In contrast, climate change mitigation means reducing greenhouse gas emissions and short-term sequestration and processing of coal and even more significantly by making infrastructural decisions that will reduce risk by reducing long-term emissions. While the entire food system is a producer of greenhouse gas emissions, still the most important component is primary production. Incentives are required to encourage producers, agribusinesses, and managers of biodiversity to follow good practices to mitigate climate change.

\section{Food Production and Climate Change}

Climate change will affect food production and welfare of food animals (i.e., livestock, poultry, and fish) in several different ways. Consider the production of livestock that will probably be restricted by climate change as consumption of water by livestock is expected to increase by a factor of three. The need for arable land for pastures and feed production will increase because of a 70\% increase in demand for agricultural products. Food safety issues also become important because around onethird of the world's cereal harvest is used for animal feed (Rojas-Downing et al. 2017). Furthermore, $14.5 \%$ of global greenhouse gas (GHG) is produced by the livestock industry. The livestock sector will therefore be a key player in reducing GHG emissions and enhancing global food security in the future (Rojas-Downing et al. 2017; Gerber et al. 2013).

Climate change and competition for land together with water and food security are likely to adversely affect livestock production at a time when it is most wanted (Thornton 2010). The output efficiency of feed conversion ratios for food, dairy, and egg production could be felt as a result of losses due to climate change. Increasing 
temperatures can also lead to death of food animals, as was noted by the deaths of more than 30,000 dairy cows in California and also in reduction of the overall production of milk in 2006 (Pitesky et al. 2014). Temperature affects most of the critical factors for livestock production, such as water availability, weight gain (feed conversion ratio), reproduction (semen quality, cow calf efficiency), and general health. A combination of increases in temperature, $\mathrm{CO}_{2}$, and variability in precipitation influences the quantity, quality, and availability of forage and grain feed crops. Livestock diseases are affected primarily by an increase in the variation in temperature and precipitation (Thornton 2010).

Changes in land use, food production, animal production, manure, storage and transportation, and livestock all influence local and global weather patterns. Production of feed and manure releases $\mathrm{CO}_{2}$, nitrous oxide $\left(\mathrm{N}_{2} \mathrm{O}\right)$, and methane $\left(\mathrm{CH}_{4}\right)$, thereby influencing climate change. Therefore, livestock production systems increase emissions of $\mathrm{CH}_{4}$. The production and transportation of animal products and improvements in land use contribute to increased $\mathrm{CO}_{2}$ emissions. Research on the impact of climate change on livestock production is still minimal and need renewed attention (IPCC 2014).

Insects are ectotherms and are highly sensitive to their surrounding environmental conditions particularly the temperature; therefore temperature is a major factor affecting their reproduction (Kambrekar et al. 2015). This means increases in temperature for both edible and disease-causing insects could increase their reproductive cycle up to five cycles in a single year, which could affect farm food production negatively in terms of crop stress and yield loss. For beneficial insects, this increase in temperature will lead to increase in their metabolism (Kambrekar et al. 2015). Perhaps this provides an opportunity to develop new food systems based on insect production, either as feed for livestock and fish or directly for human consumption.

The possible effects of changing climate on insects could result in outbreaks, migration, change in biodiversity, species extinction, change in host shift, and emergence of new pests or biotypes. Due to the climate change, there is an increase in insect pest population, more outbreaks of insects, increased number of generations, as well as development of resistant biotypes (Moore and Allard 2008).

Fish plays an important role as a source of nutrients and micronutrients for human consumption, and fishing is a crucial food-producing sector and a source of livelihood for coastal farmers. Both fisheries and aquaculture make a significant contribution to food security and the livelihoods of millions of people as job creators, nutritious food providers, revenue generators, and economic growth through harvesting, processing, and marketing fish. Especially susceptible to climate change are small-scale fisherfolk and small-scale aquaculture. Their vulnerability is the function of both their location and their circumstances of vulnerability and disadvantage. Fishing and fishing communities are exposed to extreme climatic conditions and natural hazards, such as hurricanes, cyclones, sea level rise, ocean acidification, flooding, and coastal erosion, as they are mostly situated on the coastline. Millions of people living in the lowlands of coastal regions and the floodplains cannot escape regular flooding. Climate change affects living conditions 
as well as physical well-being of humans across many agro-forest ecosystems of the world (FAO 2016).

Forests are a climate-stabilizing force. They control habitats, preserve biodiversity, play an integral role in the carbon cycle, improve living conditions, and provide goods and services that can boost sustainable growth (Bonan 2008). A forest's position in climate change is that it both causes and mitigates greenhouse emissions; therefore, there are both pros and cons. Impacts of climate change on forests result from variations in atmospheric $\mathrm{CO}_{2}$ concentration, and shifts in temperature and precipitation regimes, as well as an increase in climate variability reflected by increasing frequency and severity of extreme events. Change in climate will affect tree photosynthesis, rates of growth, leaf phenology, seed production, and cycling of nutrients (van der Meer et al. 2002). In some regions, forest form a vital resource for the community. For example, tropical forests cover about one third of the Kafa highland region of Ethiopia where a multiple tenure system exists for the utilization of the forest resources (Zewdie 2003). These include sharecropping and allocation of trees to sons when they come of age. However, the beekeeping and wood processing skills also need to pass from one generation to the next to maintain sustainable livelihoods (Zewdie 2003). Therefore, climate change effects on such forests will have a major impact on the livelihoods of the people.

The land management sector, the second largest driver of greenhouse gas emissions after the energy sector, accounts for around $25 \%$ of global emissions. Around half of these come from deforestation and habitat destruction $\left(5-10 \mathrm{Gt} \mathrm{CO}_{2} \mathrm{e}\right.$ per year). Planting of forests and commercial plantations are among the most important strategies to address climate change effects. It is estimated that 2.6 billion tons of carbon dioxide, which is one-third of $\mathrm{CO}_{2}$ from burning fossil fuels, is absorbed annually by forests. Projections show that there are nearly two billion square kilometers of worldwide degraded land - an area the size of South America - that can open up opportunities for restoration. Therefore, forest growth and preservation is an important solution to address the impact of climate change.

There are four major strategies available to mitigate carbon emissions through forestry activities:

- By reforestation (Bierbaum et al. 2013)

- Increasing the carbon content of natural forests on both stand and landscape scales

- Expansion of the use of forest products that replace $\mathrm{CO}_{2}$ emissions from fossil fuels sustainably

- Reducing deforestation and degradation emissions

Climate also adversely affects the production of food crops that are highly sensitive to climate parameters. Long-term trends in average rainfall and temperature, interannual variability in climate, shocks during specific phenological stages, and extreme weather events affect food production (IPCC 2012). Some crops are more tolerant to certain stress types than others, and different stress types affect each crop species in different ways at each phenological development stage (Simpson 
2017). Even though, crop yields are expected to decline under climatic conditions in the future, crop yields are already being affected as indicated by recent research (Ray et al. 2019).

As climate changes, crop production strategies must change also. There will always be some uncertainty associated with modeling the complex relationships between agricultural yields and future climate scenarios.

\section{Climate Change Impact on Food Availability}

Food availability is determined by the physical quantities of food that are produced, stored, processed, distributed, and exchanged (Al et al. 2008). Food production is affected by climate especially in regions where biochemical processes are being influenced by climate change. Some of these influences could be positive, negative, or even neutral (Allen Jr 1991). Location is a determinant of how the effect of climate change will be experienced in different regions (Leff et al. 2004). In temperate regions where elevated levels of $\mathrm{CO}_{2}$ will increase plant growth and development, greenhouse fertilization effect is beneficial so crop yields will also increase. Such increase is observed to be as high as $0-10 \%$ increase in crops with very high photosynthetic efficiency, while those crops with lower efficiency have higher increase from between $10 \%$ and $25 \%$. In such scenarios, the assumption is that the level of $\mathrm{CO}_{2}$ in the atmosphere will increase to 550 parts per million (Tubiello et al. 2007; IPCC 2007). In some cases, increase in temperature between $1{ }^{\circ} \mathrm{C}$ and $3{ }^{\circ} \mathrm{C}$ is beneficial to plants in temperate regions; however, in tropical and seasonally dry regions, the impact is negative on crops especially cereals that are already growing near to their optimal temperature regime. Nevertheless, the impact is negative on all crops when the increase in mean temperature is more than $3{ }^{\circ} \mathrm{C}$ (IPCC 2007).

Such temperature increase will also impact livestock production as the growth of feed crops is also compromised and become an indirect effect on livestock production (Porter and Semenov 2005). Direct effects are related to exposure to solar radiation that then affects the exchange of heat between the animal and the environment (Rust and Rust 2013). This is critical, as many livestock breeds are not tolerant of high temperatures (Rust and Rust 2013). Forage production from rangelands in Africa is sensitive to changes in climate and will have a substantial impact on the livelihoods of more than 180 million people who raise livestock on rangelands (Boone et al. 2018). Climate effects on forage quality that depends on nutrient composition and affects digestibility, partitioning of metabolized products in the digestive tract, and intake of forage by animals will strongly affect animal performance.

Some drastic changes in the farming system sometimes have to be introduced, such as a change from sheep and cattle to goats, as they are the only domesticated animals with a versatile ability to adapt to a changing climate more readily than any other ruminants. Generally, goats are less affected by the harsh hot dry climates compared with other ruminants. Some of their ability to adapt is due to their habit of 
browsing together with the anatomical advantage of the upper lips. Therefore, goats can thrive well with limited feedstuffs, especially in arid and semiarid regions (Pragna et al. 2018). Another advantage is that during feed scarcity, goats can reduce their metabolic processes to conserve energy resource (Yadav et al. 2013). Therefore, they provide a continued supply of meat despite increases in temperature and frequencies of drought.

\section{Climate Change Impact on Food Accessibility}

"Climate change is becoming something we can taste" (Little 2019). According to Little (2019), this is the age of diversity and accessibility of food. Food accessibility is a function of being able to maintain and manage what one is entitled to, which is defined as the collection of assets (including legal, political, economic, and social) needed by a person to gain access to food (Sen 1989, cited in FAO 2003, Sage 2014).

Food accessibility refers to ability to own food, distribute it, and make food choices which allows people to turn their hunger effectively into demand (Sage 2014). Since food accessibility focuses on the power of households/individuals to be able to spend money, and the group dynamics of access to food, poverty, and vulnerability are key functions of it (Ziervogel and Frayne 2011).

Households have been observed not to grow their foods independently but either buy, trade, or exchange them (Du Toit and Ziervogel 2004). The ability to acquire food by households can be impacted by climate as it influences either the job opportunities or the availability of such foods may influence non-availability of some foods leading to increase in price, which could also make such foods unaffordable, thereby impacting on individual's nutrition and health. When there is an increase in price, low-income earning families are at the receiving end, so when they cannot purchase such foods, they either eat less preferred foods or reduce quantities of food eaten, making food prices very important to food security (Pretty et al. 2005).

\section{Climate Change Impact on Food Utilization}

Food utilization refers to how food is used and how individuals can obtain vital nutrients from the food they eat. This includes the nutritional benefits of the food, the nature and method of processing the food, and the way the society views each food that also determines when if and when such foods should be eaten. Also included are the knowledge of the quality and health of the food, which determine if there would be nutrient loss or the susceptibility of the food-to-food-borne diseases if below standard (FAO 2008).

When there is insecurity of food, dietary diversity is reduced, and this could lead to non-availability of nutritious food that form basis of balanced diet of the populace. This scarcity could be as a result of water scarcity, drought, or labor from climate change and variability. This impact of climate change on food utilization is indirect 
because its effect is ultimately felt on the effect of income and capacity to purchase a diversity of foods.

The way the food is utilized by the body affects the nutritional status of individuals and informs the susceptibility of such individuals to diseases. This is observed as changes in human health that has been affected by new disease patterns created as a result of the response of different pests and vectors to climate change. As climate change increases, there are more waterborne infections and diseases in areas that are prone to flooding. This is because there will be increase in the population of pests and vectors, and new diseases will emerge, which can affect plant's growth and ultimately the food chain. As a result of the diseases, people's physiological capacity to obtain necessary nutrients from the foods consumed will be affected. Therefore, they can become nutritional food insecure despite the supply of food being sufficient (FAO 2008).

\section{Climate Change Impact on Food System}

Yields of crops particularly crops grown on an annual basis will fluctuate as a result of the change in rainfall and temperature patterns; these changes will affect the continuous supply of such crops (Al et al. 2008; Ali et al. 2014). Droughts and floods will become more frequent because of climate change, and this will adversely affect stability and availability of food leading to food security. Therefore, in local communities, the food system will be adversely affected by the timing and amount of rainfall in different seasons because most agricultural systems in such communities are rainfed (Al et al. 2008; Ali et al. 2014).

Grain reserves are used to mitigate for crop failures in disaster situations and to sustain food aid programs for displaced persons and refugees. For grain to be kept as reserves, they have to be properly stored or preserved correctly. When humidity and temperature increase because of climate change, some areas become unfit to store the grains, and additional funding will be required to store or preserve them. Invariably because of the higher cost, the ability of many underdeveloped countries to maintain sufficient grain reserves is limited or grain reserves can be inadequate to respond to natural or human disaster (Al et al. 2008; Edame et al. 2011).

\section{Impact of Climate Change Adaptation on Food Security and Nutrition}

A significant effect of global climate change is the altering of global rainfall patterns, with certain effects on agriculture (Ali et al. 2014). Climate change will have variable impacts on agriculture based on multiple factors including changes in temperature, precipitation, and humidity (Pitesky et al. 2014). Rainfed agriculture constitutes $80 \%$ of global agriculture. Many of the 852 million poor people in the world live in parts of Asia and Africa that depend on rainfall to cultivate food crops. Climate change will modify the components of the water balance, namely, rainfall, 
Table 1 The impact of climate change on food security

\begin{tabular}{l|l}
\hline Climate change & Impacts \\
\hline \multirow{4}{*}{ Increase in average temperature } & Reduced quantity and reliability of agricultural yield \\
\cline { 2 - 2 } & Increased heat stress in livestock \\
\cline { 2 - 2 } & Destruction of crops or lowering crop productivity \\
\cline { 2 - 2 } Change in amount of rainfall & $\begin{array}{l}\text { Decline in certain fish stocks due to increased sea } \\
\text { temperature }\end{array}$ \\
\hline & Reduced water availability for crop and livestock \\
\cline { 2 - 2 } & Heavy reliance on irrigation \\
\hline Increased severity of drought & Poor quality of crops due to deteriorating water quality \\
\hline \multirow{2}{*}{$\begin{array}{l}\text { Increased intensity of extreme } \\
\text { events }\end{array}$} & Increased prop yield \\
\cline { 2 - 2 } & Soil erosion \\
\cline { 2 - 2 } & Increased land degradation and desertification \\
\cline { 2 - 2 } & Inability to cultivate land \\
\cline { 2 - 2 } & Damage to crops and food stores \\
\hline
\end{tabular}

Source: Masipa (2017)

evaporation, runoff, and soil moisture storage. This means that the full crop water requirement will not be satisfied in such a growing season. Extended drought can cause the failure of small and marginal farms with resultant economic, political, and social disruption, more than is currently observed (Table 1).

\section{Crop Diseases and Effects on Crop Yields}

Crop diseases are very important because of their economic impact (Esker et al. 2012), and how they are managed can have a large influence on agricultural productivity (Savary et al. 2012; Carroll et al. 2017). The growing population of the world and the overall reduction in global production of staples such as rice and wheat due to climate change (Ray et al. 2019) are two fundamental challenges that need to be tackled, with crop protection against diseases having an obvious role to play in bringing solutions to these challenges. Crop diseases affect the life cycles of any growing plant. They affect crop production from seedling stage through budding, flowering, and fruiting until harvesting. Crop diseases that occur during seedling and budding stages will in most cases cause the death of the plants as the growing point is damaged. These deaths lead to complete crop failure and high losses. In addition, losses at the time of harvest in most cases cause the reduction in yield in terms of size and quality and thus also a reduction in overall production (Savary et al. 2012). Therefore, loss of crops caused by pests, infections, or even weeds or animal attacks is a risk to farmers, their family or household income, and food security worldwide. Losses of crops due to yield reduction can be defined qualitatively and quantitatively (Cerda et al. 2017) in terms of the reduction in the value of the crop or the financial gain from crop sales. 
In order to assess crop loss based on decrease in yield of crop, the variance between the real yield (Y) and the attainable yield that can be obtained (Ya) is taken into consideration as $\mathrm{Ya}-\mathrm{Y}$ according to the definition of crop loss by Esker et al. (2012). The attainable yield can be achieved based on the different climatic and environmental conditions at specific locations without the impact of pests, pathogens, and weeds as well as other influences that may decrease yields within available production techniques. These climatic conditions among others include temperature, rainfall, solar radiation, and soil composition. The influence of pests, diseases, and other limiting factors in the actual sense and in real-life situation is reflected on the real yield (Esker et al. 2012; Savary et al. 2006).

Plant diseases are not just important because of their impact on crop yield, which is quantitative, but also their impact on the quality of the grain or product. As crops are attacked by disease pathogens, toxins are released into these crop which reduces the quality of the crop and can also cause infection in both animals and humans (Gururani et al. 2012).

\section{Climate Change Impact on the Spread of Plant and Animal Pests and Diseases}

Climate change can influence trends in seasons and the prevalence of diseasecausing organisms and vectors and therefore also the use of herbicides and fungicides (Boxall et al. 2008). These reactions will vary among crops and geographical location. As a result of climate variability, the use of pesticide is expected to increase in the United States (Chen and McCarl 2001). Nevertheless, the estimated effects of climate change on pesticide use are a function of the type of crop and the geographical location. For example, from the United States, in Kansas and Colorado, the projected use of pesticides on wheat increased by $14 \%$ and decreased by $10 \%$, respectively, while that of Illinois differed based on which crops was planted with increases on corn and decreases on soybean by $10 \%$ and $3 \%$, respectively (Harrus and Baneth 2005). This shows that when there is an increase in temperature due to climate variability, there could be an outbreak of pests, pathogens, and/or vectors and their hosts (Lake et al. 2012). This outbreak could also lead to the use of more biocides and veterinary medicines in livestock management and eventual resurgence of antibiotic-resistant pathogens in both animal and human populations (Lake et al. 2012; Kemper 2008).

\section{Climatic Conditions Favoring Crop Diseases: Wheat Rust Disease Example}

As climate changes, the way disease pathogens adapt to the environment also changes leading to new disease occurrences (Fig. 1). For example, it was observed that warmer weather conditions favor the establishment and progress of wheat stem rust infection (Saunders et al. 2019). In certain regions of the world, during early 
growing season, high temperatures are experienced. This can cause the wheat plants that mature early to be at risk of the stem rust infection due to not being able to resist the buildup of the fungal inoculum (Saunders et al. 2019). This is because stem rust mainly needs warmer conditions for infection (Saunders et al. 2019). For example, in Germany in 2013, winter wheat production was hindered by a wet winter with low temperatures, and early warm summer temperatures led stem rust infection afterward. (Olivera Firpo et al. 2017).

\section{Climatic Change Impact Postharvest}

Over $80 \%$ of attainable yield of cotton and over $50 \%$ for other crops would be affected by pests and diseases with resulting effects on humankind. These effects which also include spoilage during postharvest and storage are felt more in resourcepoor regions (Oerke 2006). It is estimated that an average of $13 \%$ of global harvest is lost to pests and diseases, and an average of $9 \%$ to postharvest losses especially in developing countries that lack the infrastructures to store harvested crops (Oerke 2006). In some cases, such infrastructures are destroyed due to climate change such as storms, hurricanes, and tornadoes (Agrios 2005). Also, destruction caused as a result of plant diseases can be far reaching and alter the course of society and political history (Chakraborty and Newton 2011).

Storms have led to loss of crops, livestock, and infrastructure and increase in the cost of grains as a result of increase in production cost. This increase also leads to lack of resource power of the minority poor in gaining access to food and invariably increases food insecurity.

The production and quality of essential food crops are hindered by plant diseases, which also affect food quality and safety. Besides reducing yield, they have significant effects on human and animal health. As a result of global climate change, the challenge of mycotoxins and pesticide residues are serious safety issues to be mitigated (Miraglia et al. 2009). Mycotoxins are important as they cause serious health issues because of the interactions between fungus and plant cells, which are also stimulated by conducive weather conditions and the soil type. In some areas like the United States, increases in temperature increased the production of mycotoxins such as aflatoxins, while in other regions like Australia, increase in temperature could be effective in the reduction of fungal growth and invariable mycotoxin production (Russell et al. 2010; Lake et al. 2012).

Climate change may affect the transport of pathogens and chemicals into food from flooding and wind bearing aerosols from contaminated environments and may change the composition of the transported materials (Plumlee et al. 2005; Boxall et al. 2008). This is also observed in the transportation of food crops from the farm before it is consumed where higher temperatures can favor the growth and replication of bacterial population like Salmonella spp. leading to food poisoning (Lake et al. 2012). 


\section{Climate Change Impact on Microbial Biodiversity}

Climate change affects the diversity and types of macro- and microorganisms globally. Biodiversity can be measured at three levels, that is, genetic, species, and ecosystem level. Agriculture and the livelihood of most people globally depend on the genetic diversity of species and the types of species within the ecosystem (ten Kate and Laird 1999). Based on the adverse effect of chemicals in agriculture, and on human health and the environment, the use of chemicals is gradually being phased out to accommodate other techniques and technologies that can control plants and animal's pests and diseases and reduce adverse effects currently experienced by living things and the environment.

In order to achieve agricultural biodiversity, diseases and pests must be dealt with since they are one of the most deadly blows to food security. Seven thousand plant species and several thousand animal species have been used historically for human nutrition and health requirements (Toledo and Burlingame 2006). However, since the 1900 s, only 12 crops and 14 animal species now provide most of the world's food, so there is a very real threat to global biodiversity and also food security.

Soil biological management techniques can improve crop yield and quality, especially through controlling pests and diseases and enhancing plant growth. Soil biodiversity determines the resource use efficiency, as well as the sustainability and resilience of low-input agro-ecological systems, which ensure the food security of much of the world's population, especially the poor (Paoletti et al. 2000). Part of the value placed on soil biodiversity is seen in biological control of pests and pathogens that improve plant health and thus also crop production and invariably improving local food security.

\section{Biocontrol of Plant Diseases}

Biocontrol is one of the integrated disease management practices that help to reduce yield loss of crops (Thurman et al. 2017). It is the control of plant diseases by applying living biological agents or exudates from such biological agents to the plants. The application could be via foliar application to the leaves or via the roots or seed inoculation prior to planting. Most biocontrol agents (BCA) are either from the bacterial or fungal families with a few from the viral and nematodal families (O’Brien 2017; Ajilogba and Babalola 2019). Some BCAs are either rhizospheric or endospheric microbes, as they attack the pathogens using different modes including phosphate solubilization, antagonism, and hydrogen cyanide production (Ajilogba and Babalola 2016). One important fact about biocontrol is that they are specific to pathogens and sometimes to crops making them very effective. Their effectiveness is also determined by the mode of inoculation, duration of inoculation, time of inoculation, and whether they are applied singly or in a mixture. Climate change also influences biocontrol because changes in the environment affect different dimension of agricultural production. In the context of climate change, with increasing temperature and variable rainfall patterns, changes are also observed in the cycling of nutrients and amount of soil water as a result of decreases in rainfall. The rainfall pattern also affects the patterns of incidence of plant pests, pathogens, 
and diseases, and invariably food production and security are ultimately affected (Lin 2011; Fuhrer 2003; Jones and Thornton 2003).

\section{Ocean Acidification}

This is more of a recent phenomenon with climate change. It is one of the potentially most harmful and deleterious effects of climate change. Over $30 \%$ of carbon dioxide produced in the atmosphere is absorbed by sea and oceans leading to the production of acids when carbon dioxide mixes with water. Most marine creatures cannot survive at low $\mathrm{pH}$. Fish production is at a risk both directly and indirectly. The basic producers in the food chain such as planktons are also at risk, and this creates a reduction in food available to the large fish that consume then directly such as tuna, making them at risk of starving. Increasing acidity could harm shellfish by weakening their shells, which are created by removing calcium from seawater (Doney et al. 2014). Acidification also threatens the structures of sensitive ecosystems upon which some fish and shellfish rely (Hatfield et al. 2014; Ziska et al. 2016). Fish is not only a source of proteins and healthy fats but also a unique source of essential nutrients, including long-chain omega-3 fatty acids, iodine, vitamin $\mathrm{D}$, and calcium. Therefore, the effects on climate change on the acidity of the oceans will cause a decrease in annual fish caught and processed at a good source of protein for humankind. Particularly in the Asian-Pacific region, fish protein forms a vital component of the diet (Needham and Funge-Smith 2014). It is not only true for small island states, with their strong dependence upon fisheries; it was also found in continental Asian countries even far inland due to large rivers, waterways, and many rice paddies. Therefore, the importance of fish in the diet should not be overlooked in discussions on nutrition and food security and expected changes under the climate change conditions.

\section{Conclusions}

Climate change is a reality, both at global and the regional scales. The magnitude of change is still uncertain and highly variable, as is the timing of the change. However, the severe nature of the impacts which climate change could have on all sectors of Africa's economy is becoming clear. The ability of individuals and communities to adapt to climate change depends on their vulnerability, exposure, and adaptive capacity. In turn, this is related to their financial and social capital, such as social networks and community cohesion. 


\section{Recommendations}

Adaptation is a key factor that will shape the future severity of climate change impacts on food production; therefore, consideration of additional food such as underutilized crops and/or neglected foods can play a role in increasing food and nutrition supply.

There is, therefore, a need for an integrated policy approach to protect the arable land.

Further assistance needs to be given to small-scale farmers in rural areas in order to strengthen their crop production.

The restoration of forestation should be encouraged in order to make adequate use of forests to address climate change.

Globally and whenever necessary, nations should specifically relate their mitigation and adaptation initiatives to their policy decisions on environmental sustainability in agriculture industry. These policies should both be holistic and anti-poor in order to bridge the gap on the unequal effect that climate change may have on the different agricultural industries.

Consideration should be given to the economic, institutional, and social impacts of climate change by making policies that will target the global poor and vulnerable especially gender based in order to help them create communities that are resilient and robust.

Disasters caused by climate change in agriculture communities demand immediate emergency relief response and comprehensive facilities such as shelters especially in the animal farming communities. Such developments frequently involve initiatives that will provide opportunities for people to develop societies and cooperatives that are stronger and more productive and thereby becoming more selfreliant.

Adaptation and mitigation measures and strategies for climate change need to be designed and implemented through widely understood processes. Affected agricultural communities, organizations, the poor, and other vulnerable groups must be allowed to participate as stakeholders.

Global and national relevant indicators to ensure the participation of the poor and vulnerable should be developed; this could be done by keeping gender-stratified data to predict and determine the impacts of climate change on them and also their geographic locations.

Other recommendations include availability of suitable technology and decision support tools, removal of institutional barriers, and need for basic research to increase knowledge and information.

\section{Conflict of Interest}

Authors have no conflicts of interest to report. 
Acknowledgments The authors want to thank the National Research Foundation for the grant to the first author and the Agricultural Research Council - Soil, Climate, Water (ARC-SCW) for logistics.

\section{References}

Agrios G (2005) Plant pathology, 5th edn. Elsevier Academic Press, London

Ajilogba CF, Babalola OO (2016) RAPD profiling of Bacillus spp. with PGPR potential and their effects on mineral composition of tomatoes. J Hum Ecol 56(1-2):42-54

Ajilogba CF, Babalola OO (2019) GC-MS analysis of volatile organic compounds from Bambara groundnut rhizobacteria and their antibacterial properties. World J Microbiol Biotechnol 35 (6):83

Al W, Orki G, Clima O (2008) Climate change and food security: a framework document. FAO, Rome

Ali F, Thaver I, Khan SA (2014) Assessment of dietary diversity and nutritional status of pregnant women in Islamabad, Pakistan. J Ayub Med Coll Abbottabad 26(4):506-509

Allen LH Jr (1991) Effects of increasing carbon dioxide levels and climate change on plant growth, evapotranspiration, and water resources. In: Managing water resources in the west under conditions of climate uncertainty. Proceedings of a colloquium, 14-16 Nov 1990, Scottsdale, AZ. National Academy Press, Washington, DC, pp 101-147

Bierbaum R, Stults M (2013) Adaptation to climate change. Mich J Sustain 1. https://doi.org/ $10.3998 / \mathrm{mjs} .12333712 .0001 .004$

Bierbaum R, Smith J, Lee A, Blair M, Carter L, Stuart Chapin F III, Fleming P, Ruffo S, McNeeley S, Stults M, Wasley E, Verduzco L (2013) A comprehensive review of adaptation in the United States: more than before, but less than needed. Mitig Adapt Strateg Glob Chang 18(13):361406. https://doi.org/10.1007/s11027-012-9423-1

Bonan GB (2008) Forests and climate change: forcings, feedbacks, and the climate benefits of forests. Science 320(5882):1444-1449

Boone RB, Conant RT, Sircely J, Thornton PK, Herrero M (2018) Climate change impacts on selected global rangeland ecosystem services. Glob change Biol 24(3):1382-1393

Boxall AB, Hardy A, Beulke S, Boucard T, Burgin L, Falloon PD, Haygarth PM, Hutchinson T, Kovats RS, Leonardi G (2008) Impacts of climate change on indirect human exposure to pathogens and chemicals from agriculture. Environ Health Perspect 117(4):508-514

Brida A-B, Owiyo T, Sokona Y (2013) Loss and damage from the double blow of flood and drought in Mozambique. Int J Glob Warming 5(4):514-531

Carroll CL, Carter CA, Goodhue RE, Lawell C-Y (2017) Crop disease and agricultural productivity. National Bureau of Economic Research, Cambridge, MA

Cerda R, Avelino J, Gary C, Tixier P, Lechevallier E, Allinne C (2017) Primary and secondary yield losses caused by pests and diseases: assessment and modeling in coffee. PLoS One 12(1): e0169133

Chakraborty S, Newton AC (2011) Climate change, plant diseases and food security: an overview. Plant Pathol 60(1):2-14

Chen X (2015) Climate change: causes, impacts and adaptation. Project supported by Govenor State University Intellectual Life Grant, pp 1-9

Chen C-C, McCarl BA (2001) Pesticide usage as influenced by climate: a statistical investigation. Clim Chang 50(1-2):475-487

Doney S, Rosenberg AA, Alexander M, Chavez F, Harvell CD, Hofmann G, Orbach M, Ruckelshaus M (2014) Oceans and marine resources. In: Climate change impacts in the United States. The third national climate assessment. U.S. Global Change Research Program, Washington, DC. https://doi.org/10.7930/J0RF5RZW

Du Toit A, Ziervogel G (2004) Vulnerability and food insecurity: background concepts for informing the development of a national FIVIMS for South Africa. Background paper for FIVIMS-ZA consortium. http://www.agis.agric.za/agisweb/agis.html 
Edame EG, Ekpenyong AB, Fonta WM, Duru EJC (2011) Climate change, food security and agricultural productivity in Africa: issues and policy directions. Int J Humanit Soc Sci 1(21):205

Esker PD, Savary S, McRoberts N (2012) Crop loss analysis and global food supply: focusing now on required harvests. CAB Rev 7(052):1-14

FAO (2003) Focus on Food Insecurity and Vulnerability - A review of the UN System Common Country Assessments and World Bank Poverty Reduction Strategy Papers. FIVIMS Secretariat and Wageningen University and Research Centre. www.fao.org/DOCREP/006/Y5095E/ Y5095E00.htm

FAO (2008) Climate change and food security: a framework document. Food and Agricultural Organization of United Nation, Rome, Italy

Food and Agriculture Organization (FAO) (1996) Rome Declaration on world food security. FAO, Rome

Food and Agriculture Organization (FAO) (2015) The impact of natural hazards and disasters on agriculture and food security and nutrition: a call for action to build resilient livelihoods. Food and Agriculture Organization of the United Nations, Rome

Food and Agriculture Organization (FAO) (2016) Climate change and food security: risks and responses. Food and Agriculture Organization of the United Nations, Rome

Fuhrer J (2003) Agroecosystem responses to combinations of elevated $\mathrm{CO}_{2}$, ozone, and global climate change. Agric Ecosyst Environ 97(1-3):1-20

Gerber PJ, Steinfeld H, Henderson B, Mottet A, Opio C, Dijkman J, Falcucci A, Tempio G (2013) Tackling climate change through livestock: a global assessment of emissions and mitigation opportunities. FAO, Rome

Gururani MA, Venkatesh J, Upadhyaya CP, Nookaraju A, Pandey SK, Park SW (2012) Plant disease resistance genes: current status and future directions. Physiol Mol Plant Pathol 78:51-65

Harrus S, Baneth G (2005) Drivers for the emergence and re-emergence of vector-borne protozoal and bacterial diseases. Int J Parasitol 35(11-12):1309-1318

Hatfield J, Takle G, Grotjahn R, Holden P, Izaurralde RC, Mader T, Marshall E, Liverman D (2014) Agriculture. In: Climate change impacts in the United States. The third national climate assessment. U.S. Global Change Research Program, Washington, DC

ILO (2007) Employment by sector. In: Key indicators of the labour market (KILM), 5th edn. ILO, Geneva

IPCC (2007) The physical science basis. Contribution of working group I to the fourth assessment report of the Intergovernmental Panel on Climate Change. Cambridge University Press, Cambridge, UK. 996pp

IPCC (2012) Managing the risks of extreme events and disasters to advance climate change adaptation. In: CB Field, V Barros, TF Stocker, et al., editors. A Special Report of Working Groups I and II of the Intergovernmental Panel on Climate Change. Cambridge University Press, Cambridge, NY, USA

IPCC (2014) Climate change 2014, impacts, adaptation, and vulnerability, Part A: global and sectoral aspects, working group II contribution to the fifth assessment report of the Intergovernmental Panel on Climate Change. Cambridge University Press, Cambridge, UK

Jones PG, Thornton PK (2003) The potential impacts of climate change on maize production in Africa and Latin America in 2055. Glob Environ Chang 13(1):51-59

Kambrekar D, Guledagudda S, Mohankumar A (2015) Impact of climate change on insect pests and their natural enemies. Karnataka J Agric Sci 28:814-816

ten Kate K, Laird SA (1999) The commercial use of biodiversity: access to genetic resources and benefit-sharing. Earthscan, London

Kemper N (2008) Veterinary antibiotics in the aquatic and terrestrial environment. Ecol Indic 8 (1): $1-13$

Lake IR, Hooper L, Abdelhamid A, Bentham G, Boxall ABA, Draper A, Fairweather-Tait S, Hulme M, Hunter PR, Nichols G, Waldron KW (2012) Climate change and food security: health impacts in developed countries. Environ Health Perspect 120(11):1520-1526. https://doi.org/ 10.1289/ehp. 1104424

Leff B, Ramankutty N, Foley JA (2004) Geographic distribution of major crops across the world. Glob Biogeochem Cycles 18(1):GB1009. https://doi.org/10.1029/2003GB002108 
Lin BB (2011) Resilience in agriculture through crop diversification: adaptive management for environmental change. Bioscience 61(3):183-193

Little A (2019) The fate of food what we'll eat in a bigger, hotter, smarter world. Libr J 144(5):138

Masipa TS (2017) The impact of climate change on food security in South Africa: current realities and challenges ahead. Jàmbá $9(1): 1-7$

Miraglia M, Marvin H, Kleter G, Battilani P, Brera C, Coni E, Cubadda F, Croci L, De Santis B, Dekkers S (2009) Climate change and food safety: an emerging issue with special focus on Europe. Food Chem Toxicol 47(5):1009-1021

Moore B, Allard G (2008) Climate change impacts on forest health: insect pests, diseases and invasive alien species. In: International conference on adaptation of forests and forest management to changing climate with emphasis on forest health: a review of science, policies and practices, $\mathrm{p} 170$

Needham S, Funge-Smith SJ (2014) The consumption of fish and fish products in the Asia-Pacific region based on household surveys. FAO Regional Office for Asia and the Pacific, Bangkok, Thailand. RAP Publication 2015/12. 87pp

O’Brien PA (2017) Biological control of plant diseases. Australas Plant Pathol 46(4):293-304

Oerke E-C (2006) Crop losses to pests. J Agric Sci 144(1):31-43

Olivera Firpo P, Newcomb M, Flath K, Sommerfeldt-Impe N, Szabo L, Carter M, Luster D, Jin Y (2017) Characterization of Puccinia graminis $f$. sp. tritici isolates derived from an unusual wheat stem rust outbreak in Germany in 2013. Plant Pathol 66(8):1258-1266

Paoletti MG, Dufour DL, Cerda H, Torres F, Pizzoferrato L, Pimentel D (2000) The importance of leaf-and litter-feeding invertebrates as sources of animal protein for the Amazonian Amerindians. Proceedings of the Royal Society of London. Series B: Biol Sci 267(1459):2247-2252

Pitesky M, Gunasekara A, Cook C, Mitloehner F (2014) Adaptation of agricultural and food systems to a changing climate and increasing urbanization. Curr Sustain Renew Energy Rep 1:43. https://doi.org/10.1007/s40518-014-0006-5

Plumlee GS, Foreman WT, Griffin DW, Lovelace JK, Meeker GP, Demas CR (2005) Characterization of flood sediments from hurricanes Katrina and Rita and potential implications for human health and the environment. In: Science and the storms: the USGS response to the hurricanes of 2005. US Geological Survey, Denver, pp 245-256

Porter JR, Semenov MA (2005) Crop responses to climatic variation. Philos Trans R Soc B Biol Sci 360(1463):2021-2035

Pragna P, Chauhan SS, Sejian V, Leury BJ, Dunshea FR (2018) Climate change and goat production: Enteric methane emission and its mitigation. Animals 8(12):235. https://doi.org/10.3390/ ani8120235

Pretty JN, Ball AS, Lang T, Morison JI (2005) Farm costs and food miles: an assessment of the full cost of the UK weekly food basket. Food Policy 30(1):1-19

Ray D, West PC, Clark M, Gerber JS, Prishchepov AV, Chatterjee S (2019) Climate change has likely already affected global food production. PLoS One 14(5):e0217148. https://oi.org/ 10.1371/journal.pone. 0217148

Rojas-Downing MM, Nejadhashemi AP, Harrigan T, Woznicki SA (2017) Climate change and livestock: impacts, adaptation, and mitigation. Clim Risk Manag 16:145-163

Russell R, Patterson M, Lima N (2010) How will climate change affect mycotoxins in food? Food Res Int 43:1902-1914

Rust JM, Rust T (2013) Climate change and livestock production: A review with emphasis on Africa. S Afr J Anim Sci 43:255-267

Sage C (2014) Impacts of climate change on food accessibility. In Handbook of Global Environmental Change Springer Science + Business Media, pp 709-715

Saunders DG, Pretorius ZA, Hovmøller MS (2019) Tackling the re-emergence of wheat stem rust in Western Europe. Commun Biol 2(1):51

Savary S, Teng PS, Willocquet L, Nutter FW Jr (2006) Quantification and modeling of crop losses: a review of purposes. Annu Rev Phytopathol 44:89-112 
Savary S, Ficke A, Aubertot JN, Hollier C (2012) Crop losses due to diseases and their implications for global food production losses and food security. Food Secur 4(4):1-19

Simpson BM (2017) Preparing smallholder farm families to adapt to climate change. Managing crop resources. Pocket guide 2. Catholic Relief Services, Baltimore

Thornton PK (2010) Livestock production: recent trends, future prospects. Philos Trans R Soc Lond B Biol Sci 365(1554):2853-2867. https://doi.org/10.1098/rstb.2010.0134

Thurman JH, Crowder DW, Northfield, TD (2017) Biological control agents in the Anthropocene: current risks and future options. Curr Opin Insect Sci 23:59-64. https://doi.org/10.1016/j. cois.2017.07.006

Toledo A, Burlingame B (2006) Biodiversity and nutrition; a common path toward global food security and sustainable development. J Food Compost Anal 19:477-483

Tubiello FN, Amthor JS, Boote KJ, Donatelli M, Easterling W, Fischer G, Gifford RM, Howden M, Reilly J, Rosenzweig C (2007) Crop response to elevated $\mathrm{CO}_{2}$ and world food supply: a comment on "Food for thought..." by Long et al., Science 312: 1918-1921, 2006. Eur J Agron 26(3):215-223

Van der Meer PJ, Jorritsma ITM, Kramer K (2002) Assessing climate change effects on long-term forest development: adjusting growth, phenology, and seed production in a gap model. Forest Ecol Manag 162(1):39-52

Yadav B, Gynendra S, Verma AK, Dutta N, Sejian V (2013) Impact of heat stress on rumen functions. Vet World 6:992-996

Zewdie Y (2003) Forest access: policy and reality in Kafa, Ethiopia. Leisa-leusden 19:21-22

Ziervogel G Ericksen, PJ (2010) Adapting to climate change to sustain food security. Wiley Interdiscipl Rev: Climate Change 1(4):525-540

Ziervogel G, Frayne B (2011) Climate change and food security in Southern African cities. Urban food security series. Queen's University and AFSUN, Kingston/Cape Town

Ziska L, Crimmins A, Auclair A, DeGrasse S, Garofalo JF, Khan AS, Loladze I, Pérez de León AA, Showler A, Thurston J, Walls I (2016) Food safety, nutrition, and distribution. In: The impacts of climate change on human health in the United States: a scientific assessment. U.S. Global Change Research Program, Washington, DC

Open Access This chapter is licensed under the terms of the Creative Commons Attribution 4.0 International License (http://creativecommons.org/licenses/by/4.0/), which permits use, sharing, adaptation, distribution and reproduction in any medium or format, as long as you give appropriate credit to the original author(s) and the source, provide a link to the Creative Commons license and indicate if changes were made.

The images or other third party material in this chapter are included in the chapter's Creative Commons license, unless indicated otherwise in a credit line to the material. If material is not included in the chapter's Creative Commons license and your intended use is not permitted by statutory regulation or exceeds the permitted use, you will need to obtain permission directly from the copyright holder.

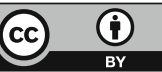

